\title{
Gender Gaps in Political Participation Across Sub-Saharan African Nations
}

\author{
Hilde Coffe $\cdot$ Catherine Bolzendahl
}

Accepted: 16 June 2010/Published online: 22 July 2010

(C) The Author(s) 2010. This article is published with open access at Springerlink.com

\begin{abstract}
A substantial literature has studied gender differences in political participation in Western industrialized democracies, but little is known about such gaps in sub-Saharan African nations. Using 2005 Afrobarometer data, this paper presents a systematic investigation of the gender gap in political participation across 18 sub-Saharan African countries. In line with cultural isomorphism, patterns in gender gaps across different types of participation generally mirror those of Western democracies, with small to no gender gaps in registration to vote, but substantial gaps in less institutionalized types of participation. Yet, the remaining large gaps cannot be explained by gender differences in socioeconomic characteristics and political attitudes as suggested in studies on Western industrialized nations. Finally, substantial cross-national differences within the sub-Saharan African are found, substantiating the importance of more fine-grained examinations of variation across sub-Saharan African nations.
\end{abstract}

Keywords Political participation · Sub-Saharan Africa $\cdot$ Gender

\section{Introduction}

Political participation is good for democracy, but all democracies are plagued by systematic inequalities in participation (Lijphart 1997; Galston 2001). One of the most persistent has been according to gender, such that women are found to participate less than men, and suggesting that half the population's interests are less well represented (Andersen 1975; Schlozman et al. 1994). Yet, the vast majority of research on gender gaps in political participation is based on patterns occurring in Western industrialized democracies (largely the U.S. and Western Europe), raising questions about the applicability of findings and explanations for gender differences in developing democracies.

\footnotetext{
H. Coffe ( $\square)$

Utrecht University, Utrecht, The Netherlands e-mail: h.r.coffe@uu.nl

C. Bolzendahl

University of California, Irvine, Irvine, CA, USA
} 
To help address such questions, we conduct a systematic investigation of the gender gap in different types of participation across 18 sub-Saharan African nations, using 2005 Afrobarometer data. In evaluating whether prior research on gender gaps in political participation in industrialized nations can be usefully extended, two related aspects are investigated. First, whether the pattern in, and size of, gender gaps across different types of political participation in sub-Saharan African nations are similar to those found in previous research on Western nations, and second, the extent to which standard explanations for the gender gap (i.e., gender differences in socioeconomic resources and political attitudes) substantially mediate gaps found in the sub-Saharan African nations. Such an analysis of sub-Saharan African nations opens additional research opportunities to explore questions of the influence of modernization or cultural isomorphism and speaks to the large debate about gender equality across the globe (Desposato and Norrander 2009; Inglehart and Norris 2003; Meyer et al. 1997). Moreover, by focusing on a sample of individual nations, it counters a tendency of treating sub-Saharan Africa as a monolithic bloc of poor, underdeveloped or agrarian nations.

The paper proceeds as follows. We review past research on gender and political participation, the relevance of these debates to African nations, and findings from the small literature therein. We also consider the unique advantages of studying political participation in Africa, and introduce our data, measures and methods. After describing the extent of the gender gap between the different sub-Saharan African nations, we turn to multivariate analyses investigating the extent to which gender gaps can be explained by gender differences in socioeconomic and attitudinal characteristics. We next explore potential connections between a given nation's political, social and economic context and the extent of gender gaps in participation. We conclude with an overview of the core findings, and the contributions made to understanding political participation in sub-Saharan Africa.

\section{Gender Gaps in Political Participation}

Gender inequalities in political participation remain an important part of “democracy's unresolved dilemma" of unequal participation (Lijphart 1997). For these reasons a great deal of research has been devoted to evaluating gender gaps in political participation. Questions mainly center on whether a gap exists, how large it is, and where it occurs. Below we briefly review findings on these questions based on Western industrialized democracies, and implications for sub-Saharan African nations.

\subsection{The Size and Pattern of Gender Gaps in Western Industrialized Democracies}

Based on research that focuses on gender gaps in political participation among Western industrialized democracies, the "good news" is that gender differentials in one of the most important forms of participation—voting—are shrinking to the point of insignificance and, in some countries, even reversing (Coffé and Bolzendahl 2010; Currell 2005; Parry, Moyser and Day 1992; Uhlaner 1989; Verba et al. 1997). Nevertheless, gender gaps persist in most other types of political participation, and men are significantly more involved than women in a number of outlets such as strikes, demonstrations, contacting political officials, and political party membership (Coffé and Bolzendahl 2010; Inglehart and Norris 2003; Marien et al. 2010). Thus, gender remains a meaningful source of inequality in political participation.

Clearly, the gender gap varies according to how participation is measured. Among the more "institutional" forms of participation, while voting gaps appear to be shrinking, 
participation in political parties and running for office remain dominated by men (Paxton et al. 2007). Among the less institutional, or more informal, forms of participation, gender difference patterns vary even further (Coffé and Bolzendahl 2010), and scholars increasingly emphasize the importance of less institutional forms of participation (Dalton 2008; Marien et al. 2010). Women tend to be as likely, or more so, as men to engage in individualistic forms of participation such as signing a petition, political consumerism, or donating money. Men however, are more likely than women to engage in collective forms of participation (e.g., a demonstration) or to directly contact a politician (Burns 2007; Coffé and Bolzendahl 2010; Marien et al. 2010; Parry et al. 1992; Pattie et al. 2003). Together, these findings suggest any consideration of gender differences should include measures of participation beyond the ballot box.

\subsection{Gender Gaps in Sub-Saharan Africa: Modernization Versus Cultural Isomorphism?}

There is very little research testing the size or scope of the gender gap in political participation among sub-Saharan African nations. However, studying these nations not only allows us to see if findings and assumptions based on Western democracies hold true in less-developed regions, but may also provide insight into broader questions concerning theories of modernization and cultural isomorphism. More specifically: Do gender gaps in political participation among sub-Saharan African states reflect outcomes based on their modernization status or might "world society" affect nations beyond their level of modernization?

The modernization approach generally argues that as incomes rise, women gain economic resources, more egalitarian sex roles emerge, and cultural values change, leading to increasing levels of female participation in political life (Inglehart 1990, 1997) and implicitly fits with the classic linear understanding of citizenship rights (Marshall 1950). The linear assumptions embedded in this description of the modernization approach have been rejected to a certain degree and reformulated as involving contingent processes of path dependence and cultural influence (Inglehart and Norris 2003, 2005; Inglehart and Welzel 2005). ${ }^{1}$ Regardless, the implication of such assumptions is that women's gains will be dependent on the nations' greater economic and political development as it impacts cultural/social values. Based on this perspective, we would expect gender gaps to be much larger in sub-Saharan African nations than those found in research on Western nations because sub-Saharan African nations lag behind in their economic and political development and associated cultural attitudes (e.g., rational and self-expression values) (Inglehart and Norris 2003, 2005).

In support of modernization-based understandings of women's political inequality, the limited research on gender gaps in political participation in sub-Saharan African nations suggests the size of the gender gap is substantial across these countries. Despite impressive gains in many nations in access to de jure equality (McEwan 2005) and formal political representation (Geisler 2004; Ballington 1998, 2004), scholars agree that women in subSaharan African nations face pervasive oppression in terms of exclusion from leadership roles, resources to mobilize, private patriarchy, and male control over female political spaces (Beck 2003; Bratton 1999; Geisler 1995, 2004; McEwan 2000, 2003). All of these factors are likely to block women's participation in political life.

\footnotetext{
1 This issue is pursued in much greater detail in a response by Inglehart and Norris (2005) describing and defending modernization theory in a response to critiques by Adams and Orloff (2005a), but see response by Adams and Orloff (2005b).
} 
As might be expected based on modernization theory, a study of political participation in Zambia finds that gender is one of the most consistent determinants of unequal participation (Bratton 1999). Yet, the results are not unequivocal. Men and women are equally likely to register to vote and to engage in communal political activities (e.g., meetings and rallying). However, men who were registered to vote were much more likely than women to actually do so, and men were more likely to contact political officials. Thus, the Zambian findings support conclusions reached in Western research that gender gaps vary by type of participation, and this variation suggests modernization cannot fully explain gender gaps in political participation.

The lack of a consistent, large gender gap across forms of participation suggests a number of further questions, which have also been raised in recent critiques of modernization approaches in regard to gender (Adams and Orloff 2005a, b; Adams et al. 2005; Young 2003, 2005). It has been argued that modernization approaches inadequately identify and problematize uneven processes internal to modernization and that alternative approaches are required that acknowledge systematic and unequal power relationships between and within states that help structure outcomes (Adams and Orloff 2005a, b). Thus in order to gain a complete understanding of gender inequality in developing nations, the generalizations contained within modernization theory may be inadequate (Desposato and Norrander 2009). ${ }^{2}$ Even in Western nations, feminist state scholars note that gains in women's equality have been uneven, with women achieving rights in piecemeal fashion (contrary to assumptions in Marshall (1950)) (Pateman 1988 [1970]). Similarly, prior research finds that many sub-Saharan African women have gained public political rights that are not matched privately or informally, and de facto access to civil rights may lag in nations that otherwise make progressive social rights guarantees (e.g., South Africa) (Bauer 2009, p. 194; Beck 2003; Lindberg 2004; Nisbet 2008).

Given these issues, it is helpful to incorporate insights from research on world society, particularly the concept of cultural isomorphism (Meyer et al. 1997). Such an approach highlights the ways in which global ideas about women's political involvement and equality may have strongly influenced gender gaps in participation across the globe. Specifically, women's rights in African nations are not developing in a vacuum. International connections diffuse norms and ideas (Gray et al. 2006), and events outside subSaharan Africa in countries as varied as the Soviet Union, East Germany, and China, have been presented as influential factors for the contents of demands and the timing of protests in sub-Saharan Africa in the beginning of the nineties (Bratton and van de Walle 1992), illustrating the "diffusion effect" of successful democratic revolutions across the globe. Moreover, Western colonial legacies continue to shape the political institutions of these nations, reinforced by donor pressure (e.g., the IMF) and Western (governmental and nongovernmental) organizations focused on women's political equality. Specifically, in 1975 the UN began the "Decade for Women," and since then numerous UN women's conferences have been actively used by women from African nations to pursue greater roles in their own countries (Geisler 2004). Additionally these nations have faced regional pressures from groups such as the African Union and the Protocol on the Rights of Women in Africa to implement policies to improve the lives of women (Scribner and Lambert 2010).

\footnotetext{
${ }^{2}$ We note that Adams and Orloff $(2005 \mathrm{a}, \mathrm{b})$ accept the basic premise of modernization as a positive influence on gender equality and women's lives in general, instead calling for a more contextual approach that can speak directly to "aberrations" in modernity and the progress of women's rights, among other issues. In comparison, other scholarship more fundamentally rejects modernization as a progressive force (Young 2003, 2005).
} 
Taken together, these factors are not a rejection of the influence of modernization, per se, especially given that many of the factors described above (e.g., the UN) might be seen as outcomes of the global modernizing process (Adams and Orloff 2005a, b). However, to the extent that the modernization approach underestimates the influence of global society, we suggest the utility of the cultural isomorphism perspective which expects many features of nation-states to "derive from worldwide models constructed and propagated through global cultural and associational processes" (Meyer et al. 1997, p. 144). Thus, global processes diffusing models of gender equality and participation across sub-Saharan Africa would suggest that gender patterns of political involvement are not substantially different from those found in studies on the West.

Theories of modernization and cultural isomorphism lead to different assumptions regarding the overall size and pattern of gender gaps in sub-Saharan Africa, but largely ignore differences internal to this region. Relative to Western democracies, nations in SubSaharan Africa may share more similarities than differences, but such an approach obscures important economic and political differences between the nations, different colonial heritages, and divergent trajectories towards and citizens' attitudes to democracy (Bratton 2007). Recognizing these cross-national differences within the region of subSaharan Africa and their potential effect on the gender gap in political participation, we analyze each nation individually in the results that follow as well as descriptively analyzing important contextual influences unique to each nation.

\section{Sources of Gender Gaps in Political Participation}

In addition to considering whether the size and pattern of gender gaps in political participation in sub-Saharan African nations resemble gaps found in previous research on Western nations, we also explore the extent to which common explanations of gender gaps presented in research on Western industrialized nations can be extended to nations in the region of sub-Saharan Africa. Hereafter, we briefly present explanations for gender gaps in Western Industrialized nations and to what extent they may be relevant in the study on subSaharan African nations.

\subsection{Explaining Gender Gaps in Western Industrialized Democracies}

Previous research on gender gaps in political participation among Western industrialized nations has proposed at least two sets of explanations. First, it has been found that a significant portion of the gap is due to systematic individual-level differences between men and women in terms of socioeconomic resources. This research argues that women are less likely to engage in politics because of their lower access to such resources. For example, men are far more likely to be employed full-time than women, and employment is positively related to political participation, information and efficacy among U.S. respondents (Schlozman et al. 1994, 1999). Further, women (employed or not) are more likely to be burdened with house and care work, placing further demands on their time and resources, leaving them less available for political participation (Burns et al. 1997). Thus, controlling for characteristics such as employment, education, marital status, and parental status is found to mediate a substantial portion of a gender gap in participation (Burns 2007; Harrison and Munn 2007).

Other research suggests there is an independent influence of attitudes on participation and that regardless of socio-economic resources, political engagement requires motivation 
and interest (Inglehart and Norris 2003). U.S. research suggests women's lower levels of political information, interest, and efficacy are important explanations for a gender gap independent of other characteristics (Verba et al. 1997). Women's lack of political interest and information may be rooted in social processes of gender socialization both as children and adults (Burns 2007; Lovenduski 2005; Rapoport 1981; Verba et al. 1997). Women are socialized toward a gender role that is more passive, private, rule-abiding, and compassionate, while men are oriented toward leadership, public roles, autonomy and self-reliance (Brownmiller 1984; Fox and Lawless 2004; West and Zimmerman 1987). This socialization may contribute to women's lower levels of political engagement (Atkeson and Rapoport 2003; Rapoport 1981) with differences in political attitudes and participation beginning early in life (Fridkin and Kenney 2007; Hooghe and Stolle 2004) and continuing over the life course (Alwin et al. 1991). Thus, controlling for political attitudes has also been found to substantially mediate gender differences in political participation (Verba et al. 1997).

\subsection{Explaining Gender Gaps in Sub-Saharan African Nations}

Whether the explanations for gender gaps in participation from Western democracies can be extended to sub-Saharan African nations remains unclear. Participation may follow different patterns in fragile, new democracies compared to established democracies (Bratton 1999). Research explaining gender gaps in political participation across African nations is extremely limited, and the Western-based measures of individual socio-economic and attitudinal explanations of the gender gap may have to be reconsidered. More generally, Dalton et al. (2009:72) conclude that "democratic institutions facilitate the translation of individual resources into political action," suggesting that socioeconomic characteristics will have a stronger affect on engagement in political activities in rich democratic societies than in poorer, less-democratic societies. Bratton's (1999) study of Zambia shows that the standard socioeconomic status and political attitude variables have little explanatory power in explaining political participation.

Looking to the experiences of women in sub-Saharan African exemplifies why standard accounts may not hold. For example, women's participation in the economy is not as strongly linked to control or autonomy as it might be in Western nations (Geisler 2004). More specifically, Western colonial culture emphasized the ideal of the "real housewife," with women as the primary providers of unpaid family labor and men as public, political figures (Geisler 2004), but in reality sub-Saharan African women were pressured to remain active in the formal (and informal) economy-typically without supportive rights. All of this has contributed to a type of de facto economic marginalization that may be independent of actually employment status, and is further exacerbated by the fact that unemployment hits African women harder than men (McEwan 2000).

In terms of marital roles, colonialism sometimes inadvertently made marriage more financially advantageous to women by changing divorce laws to reflect Western mores (Geisler 2004), but women may still struggle under "customary" marriages arrangements that offer women few rights and lower status (McEwan 2000). In some ways these mirror Western stories about women's lower access to resources, including findings that African women have unequal access to education and evidence of a positive relationship between education and support for democracy (Evans and Rose 2007; Lindberg 2004), but in other ways it highlights the ways in which women's and men's negotiation of work and family roles may be quite different. Thus, it is unclear whether standard controls substantially mediate gender gaps among the nations we investigate. 


\section{Data and Measurements}

To answer our research question on a gender gap in political participation in Africa, we use data from the 2005 Afrobarometer Survey, a public attitude survey on democracy, market reform and civil society. The survey is a collaborative effort of 18 research institutes in various sub-Saharan African nations: Benin, Botswana, Cape Verde, Ghana, Kenya, Lesotho, Madagascar, Malawi, Mali, Mozambique, Namibia, Nigeria, Senegal, South Africa, Tanzania, Uganda, Zambia, and Zimbabwe. ${ }^{3}$ For each country a national probability sample that represents an accurate cross section of the voting age population is interviewed. Random selection is used at every stage of sampling and the sample is stratified to ensure that all major demographic segments of the population are covered. Interviews were conducted face-to-face by trained interviewers in the language of the respondent's choice. Further details on the survey can be found in the survey manual of Afrobarometer Network (Carter 2008) or on www.afrobarometer.org, where data are publically available.

\subsection{Dependent Variables}

Three different types of political participation: registration to vote ${ }^{4}$ collective action and contact. To assess voting registration, the survey asks: "Understanding that some [Ghanaians/Kenyans/etc.] were not able to register as voters for the [20XX] elections; which statement is true for you?" Responses include: (1) you were registered to vote; (2) you did not want to register; (3) you could not find a place to register; (4) you were prevented from registering; (5) you were too young to register; (6) you did not register for some other reason. The variable was recoded into a dichotomous yes/no response, and 80 percent of respondents said they registered.

Our second type of political participation refers to collective action and is assessed by a sum scale of two items: "attending a community meeting" and "joining others to raise an issue." Respondents are asked whether they have done the activity during the past year, and if not, whether they would do it if they had the chance. Answer categories are (0) no, would never do this; (1) no, but would do if had the chance; (2) yes, once or twice; (3) yes, several times; (4) yes, often. The sum scale was rescaled to be continuous within this range.

Contacting political institutions and/or persons is a sum scale, made from four items, all asking "during the past year, how often have you contacted any of the following persons for help to solve a problem or to give them your views," with the following persons/ institutions mentioned: local government councilor, a Member of Parliament/National Assembly Representative, an official of a government ministry, or a political party official. For each question, respondents could choose between four answers, running from (0) never to (3) often. The additive scale was rescaled to be continuous within this range.

\footnotetext{
3 Data for contacting politicians and political institutions are missing for Zimbabwe.

4 We do not include the act of voting since among those who had registered to vote, more than 93.5 percent claimed to have voted. Such limited variation makes it impossible to perform reliable regression analyses. Explorative bivariate analyses indicate that the patterns of gender gaps in actual voting are similar to those found for registration to vote (presented below). With the exception of Zambia where a small significant gender gap is found for voting whereas no significant gender effect is found for registration to vote. In those countries where significant bivariate gender gaps are found with respect to registration to vote, significant gender gaps in voting are also apparent.
} 


\subsection{Explanatory Variables}

The main focus of the analysis, gender, is measured as a dichotomous variable with 0 for male and 1 for female respondents.

To test socioeconomic explanations for the gender gap, we include age, religion, education, employment status, place of residence, and poverty. Age is a continuous variable. Respondents older than $99(n=7)$ were excluded from the analyses. We also introduced a squared value for age to control for non-linearities in the effect as a life-course control. Religion is a dummy variable distinguishing Christians from those affiliated with all other religions and the non-religious. ${ }^{5}$ Church attendance is treated as a continuous variables ranging from (0) never attend to (5) attend more than once a week. Education is measure by three categories: not completed primary school, completed primary school, and completed secondary school or higher. Employment is a dummy variable indicating whether a person is currently employed part or full-time versus not employed. Place of residence is self-assessed as either rural (0) or urban (1). Finally, poverty adds five similarly scaled items measuring how often (ranging from (0) never to (4) always) the respondent or anyone from his/her family has gone without "enough food to eat," "enough clean water for house use," "medicines or medical use," "enough fuel to cook food," and "a cash income" $(\alpha=.78)$.

We also assess the influence of three indicators of political attitudes: trust in political institutions or political agents, political efficacy and interest in public affairs. We measure trust in political institutions through trust in six types of political institutions or agents: the president, parliament/national assembly, electoral commission, elected local government council, ruling party, opposition political parties $(\alpha=.83)$. Each has a possible response of (0) not at all; (1) just a little; (2) somewhat; (3) a lot. Our indicator of political efficacy is based on a Likert-scaled item asking "Do you agree or disagree with the following statement: Politics and government sometimes seem so complicated that you can't really understand what's going on." The possible answers range from (0) strongly agree to (4) strongly disagree. Finally, one question is used to measure interest in public affairs: "How interested would you say you are in public affairs?" The possible answers range from (0) not at all interested to (3) very interested. Means for all dependent and explanatory variables, divided by gender subgroup, are provided in the "Appendix".

Missing values were estimated through multiple imputation by chained equation (generally known as MICE). ${ }^{6}$ This technique uses information in the observed data to predict the likely values of the unobserved data and has shown to outperform other commonly employed techniques for dealing with missing data such as listwise deletion,

\footnotetext{
5 The non-religious group was too small to include as a separate group. Additional models for those countries where the non-religious group was large enough to consider as a separate category showed similar results as those with the dummy variable for religious denomination. In most nations included in our analyses, Christians form a (large) majority among the citizens. Notable exceptions include Mali and Senegal which are majority Islamic African states. In our dataset, more than 95 percent of the respondents of these countries belong to the Islam. In Botswana about 43 percent of the respondents are Christian, 29 percent belong to "another" religion (i.e., a religion other than Islam or Christianity), and almost 28 percent claim no religion.

${ }^{6}$ Only 18,693 respondents of the 25,311 total cases that answered on the registration to vote question had complete information on all independent variables (i.e., all individual items that were used to compute some variables) included in the full models presented below. For the dependent variable collective action, the 2005 Afrobarometer contained full information on all independent variables for 18,590 respondents of the 25,074 cases. The dataset contained full information on all dependent variables for 17,741 respondents of the 24,091 cases that answered the questions on our third type of participation, contacting.
} 
pairwise deletion, mean imputation, or dummy variable adjustment (Allison 2002). We used ICE in Stata 10 (Royston 2004), taking all independent variables as predictors and generated ten imputations, each of which replaced cases with missing information with plausible values based on their predictive distributions. We ran identical models for each of the imputed data sets, using complete data on all independent variables. We then combine these results to produce overall estimates and significance levels. All the results presented in the proceedings tables and graphs are the combined results across datasets (Rubin 1987).

\subsection{Analytical Strategy}

In the analyses below we examine gender differences in political participation across 18 sub-Saharan African nations. We present three models for gender gaps in each type of political participation. First, bivariate models without controls, second a model with controls for socioeconomic factors, and third a model containing both socioeconomic and political attitudinal controls. In each we focus only on the gender gap in participation, but full results are available upon request.

Registration to vote is predicted with binary logistic models, and ordinary least squares models are used to analyze the respondents' level of collective action and political contact. Since cross-national differences in gender and political participation within the region of sub-Saharan Africa have - to the best of our knowledge - not been studied in detail before, we present results for each nation individually. Other approaches (e.g., multi-level models) would necessarily obscure important differences among the nations, as is common in global research on the topic (Inglehart and Norris 2003; Meyer et al. 1997). Moreover, the number of countries included in our study is too limited to perform a robust multilevel analysis (Van der Meer et al. 2010). Instead, we conclude our analysis with a descriptive and exploratory approach to the link between macro-level variation and gender gaps found in each of the nations.

\section{Gender Gaps in Political Participation Across Sub-Saharan African Nations}

\subsection{Registration to Vote}

We first consider the gender gap in the probability of registering to vote in Table 1.

The bivariate models indicate a significant gender gap in ten of the eighteen nations included in our study, with women significantly less likely to register to vote in Benin, Kenya, Madagascar, Mali, Mozambique, Namibia, Nigeria, Uganda, Senegal and Tanzania. However, in every nation but Kenya and Nigeria the gap is no longer significant once we control for socioeconomic characteristics. Thus, the gender gap in voter registration can be explained by gender differences in socioeconomic status. In the final model, we also include controls for political attitudes, and a significant gender gap only remains in Kenya, suggesting Kenyan women are more marginalized from this form of participation regardless of their socioeconomic status or interest in politics. Further tests (not shown) ${ }^{7}$ comparing the

\footnotetext{
${ }^{7}$ Logistic regressions confound the size of the effect with the error variance, limiting the applicability of linear tests of coefficients across models (Mood 2010; Long 2007). Unfortunately, the use of MICE for missing values precludes the calculation of other effects, which are directly comparable (e.g., predicted probabilities), thus we used linear tests for the equality of coefficients across models (Paternoster, et al. 1998) $(p \leq .05$ in a two-tailed test):
} 
Table 1 Binary logistic regression results for women's registration to vote ( $t$-statistics in parentheses) in 18 sub-Saharan African nations

\begin{tabular}{|c|c|c|c|c|c|c|c|}
\hline \multirow[t]{2}{*}{ Nation } & \multicolumn{2}{|l|}{ Bivariate } & \multicolumn{2}{|c|}{ Socioeconomic $^{\mathrm{a}}$} & \multicolumn{2}{|c|}{ Political attitudes ${ }^{b}$} & \multirow[t]{2}{*}{$N$} \\
\hline & $B$ & $t$ & $\beta$ & $t$ & $\beta$ & $t$ & \\
\hline Benin & $-.43^{*}$ & $(-2.16)$ & -.46 & $(-1.95)$ & -.38 & $(-1.58)$ & 1,198 \\
\hline Botswana & .05 & $(.35)$ & .09 & $(.62)$ & .13 & $(.84)$ & 1,199 \\
\hline Cape Verde & -.07 & $(-.49)$ & -.01 & $(-.07)$ & $<.01$ & $(.01)$ & 1,247 \\
\hline Ghana & .08 & $(.33)$ & .10 & $(.37)$ & .15 & $(.57)$ & 1,184 \\
\hline Kenya & $-.85 * * *$ & $(-6.46)$ & $-.86 * * *$ & $(-5.27)$ & $-.85 * * *$ & $(-5.05)$ & 1,274 \\
\hline Lesotho & .08 & $(.53)$ & .27 & $(1.50)$ & .33 & (1.79) & 1,157 \\
\hline Madagascar & $-.51 * *$ & $(-3.35)$ & -.28 & $(-1.56)$ & -.22 & $(-1.21)$ & 1,340 \\
\hline Malawi & -.07 & $(-.47)$ & .10 & $(.59)$ & .13 & $(.75)$ & 1,199 \\
\hline Mali & $-.71 * * *$ & $(-4.23)$ & -.31 & $(-1.54)$ & -.31 & $(-1.53)$ & 1,238 \\
\hline Mozambique & $-.51 * *$ & $(-2.91)$ & -.30 & $(-1.59)$ & -.27 & $(-1.40)$ & 1,194 \\
\hline Namibia & $-.30^{*}$ & $(-2.04)$ & -.14 & $(-.80)$ & -.09 & $(-.51)$ & 1,198 \\
\hline Nigeria & $-.57 * * *$ & $(-5.99)$ & $-.31 * *$ & $(-2.93)$ & -.17 & $(-1.53)$ & 2,360 \\
\hline Senegal & $-.64 * * *$ & $(-5.07)$ & -.28 & $(-1.78)$ & -.25 & $(-1.56)$ & 1,189 \\
\hline South Africa & .09 & $(.87)$ & .10 & $(.90)$ & .16 & $(1.34)$ & 2,390 \\
\hline Tanzania & $-.51 * *$ & $(-3.43)$ & -.20 & $(-1.05)$ & -.20 & $(-1.02)$ & 1,300 \\
\hline Uganda & $-.36^{* *}$ & $(-3.48)$ & -.14 & $(-1.10)$ & -.03 & $(-.20)$ & 2,398 \\
\hline Zambia & -.21 & $(-1.71)$ & -.04 & $(-.29)$ & .01 & $(.07)$ & 1,199 \\
\hline Zimbabwe & -.03 & $(-.16)$ & -.01 & $(-.05)$ & .06 & $(.33)$ & 1,047 \\
\hline
\end{tabular}

$* p<.05 ; * * p<.01 ; * * * p<.001 ;$ two-tailed tests Source: Afrobarometer 2005

Bold values indicate coefficients are significantly different $(p<.05$; two-tailed test) from bivariate model a Model controlling for age, age square, education, religious denomination, church attendance, employment, urban residence, poverty

b Socioeconomic model plus controls for trust in political institutions, political efficacy and interest in public affairs

coefficients across models indicate that standard socioeconomic and attitudinal controls only significantly mediate the gender gap in registration to vote in Nigeria and Uganda.

\subsection{Collective Action}

In Table 2 we look at the gender gap in collective action, where bivariate models indicate significant gender gaps in all nations except Namibia, and these gender gaps remain significant in all nations but Mozambique when socioeconomic characteristics are added. Conversely, in Namibia, once socio-economic variables are controlled for, women are more likely than men to participate, and the gap grows when political attitudes are taken

Footnote 7 continued

$z=\frac{\left(b_{1}-b_{2}\right)}{\sqrt{\mathrm{SE}_{1}^{2}+\mathrm{SE}_{2}^{2}}}$ 
Table 2 Regression results for women's participation in collective action (standard errors in parentheses) in 18 sub-Saharan African nations

\begin{tabular}{|c|c|c|c|c|c|c|c|}
\hline \multirow{2}{*}{$\frac{\text { Nation }}{\text { Benin }}$} & \multicolumn{2}{|l|}{ Bivariate } & \multicolumn{2}{|c|}{ Socioeconomic $^{\mathrm{a}}$} & \multicolumn{2}{|c|}{ Political attitudes ${ }^{\mathrm{b}}$} & \multirow{2}{*}{$\frac{N}{1,187}$} \\
\hline & $-.61 * * *$ & $(.06)$ & $-.62 * * *$ & $(.06)$ & $-.54 * * *$ & $(.06)$ & \\
\hline Botswana & $-.22 * * *$ & $(.06)$ & $-.23 * * *$ & $(.06)$ & $-.20 * * *$ & $(.05)$ & 1,188 \\
\hline Cape Verde & $-.31 * * *$ & $(.05)$ & $-.34 * * *$ & $(.06)$ & $-.29 * * *$ & $(.05)$ & 1,223 \\
\hline Ghana & $-.45 * * *$ & $(.06)$ & $-.38 * * *$ & $(.06)$ & $-.34 * * *$ & $(.06)$ & 1,180 \\
\hline Kenya & $-.37 * * *$ & $(.06)$ & $-.30 * * *$ & $(.06)$ & $-.19 * *$ & $(.06)$ & 1,271 \\
\hline Lesotho & $-.56^{* * *}$ & $(.06)$ & $-.58 * * *$ & $(.06)$ & $-.50 * * *$ & $(.06)$ & 1,159 \\
\hline Madagascar & $-.42 * * *$ & $(.05)$ & $-.37 * * *$ & $(.05)$ & $-.30 * * *$ & $(.05)$ & 1,333 \\
\hline Malawi & $-.16^{* *}$ & $(.05)$ & $-.14 * *$ & $(.05)$ & $-.11 *$ & $(.05)$ & 1,194 \\
\hline Mali & $-.60 * * *$ & $(.07)$ & $-.45 * * *$ & $(.07)$ & $-.43 * * *$ & $(.07)$ & 1,243 \\
\hline Mozambique & $-.14^{*}$ & $(.07)$ & -.08 & $(.07)$ & -.07 & $(.07)$ & 1,169 \\
\hline Namibia & .09 & $(.07)$ & $.15^{*}$ & $(.06)$ & $.17 * *$ & $(.06)$ & 1,179 \\
\hline Nigeria & $-.70 * * *$ & $(.05)$ & $-.58 * * *$ & $(.04)$ & $-.51 * * *$ & $(.04)$ & 2,315 \\
\hline Senegal & $-.32 * * *$ & $(.08)$ & $-.24 * *$ & $(.08)$ & $-.21 *$ & $(.08)$ & 1,167 \\
\hline South Africa & $-.21 * * *$ & $(.05)$ & $-.24 * * *$ & $(.05)$ & $-.19 * * *$ & $(.05)$ & 2,356 \\
\hline Tanzania & $-.54 * * *$ & $(.06)$ & $-.45 * * *$ & $(.06)$ & $-.39 * * *$ & $(.06)$ & 1,281 \\
\hline Uganda & $-.43 * * *$ & $(.04)$ & $-.34 * * *$ & $(.04)$ & $-.28 * * *$ & $(.04)$ & 2,391 \\
\hline Zambia & $-.16^{* *}$ & $(.05)$ & $-.12 *$ & $(.05)$ & -.06 & $(.05)$ & 1,194 \\
\hline Zimbabwe & $-.15^{*}$ & $(.07)$ & $-.14 *$ & $(.07)$ & -.08 & $(.07)$ & 1,044 \\
\hline
\end{tabular}

$* p<.05 ; * * p<.01 ; * * * p<.001$; two-tailed tests Source: Afrobarometer 2005

Bold values cells indicate coefficients are significantly different $(p<.05$; two-tailed test) from bivariate model

a Model controlling for age, age square, education, religious denomination, church attendance, employment, urban residence, poverty

b Socioeconomic model plus controls for trust in political institutions, political efficacy and interest in public affairs

into account. However, only in Zambia does controlling for political attitudes ameliorate a significant gender gap in collective action.

Overall, standard controls for socioeconomic status and political attitudes do not mediate much of the gender gap in collective action. A comparison of the coefficients across models ${ }^{8}$ indicates only three nations experience significant declines in the gender gap once both socioeconomic status and political attitudes are included: Kenya, Nigeria and Uganda. However, in none of these nations does the gender gap disappear suggesting that even where standard accounts explain a significant portion of the gender gap, women are far less likely than men to participate.

\subsection{Contacting Political Officials or Institutions}

Finally, we consider gender gaps in political contact in Table 3. Bivariate models reveal significant gender gaps in all sub-Saharan African nations with the exception of Botswana Namibia, showing that in all other nations, women are significantly less likely than men to

\footnotetext{
${ }^{8}$ Results obtained using linear tests of the equality of coefficients across models (Paternoster, et al. 1998) $(p \leq .05$ in a two-tailed test).
} 
Table 3 Regression results for women's engagement in political contact (standard errors in parentheses) in 17 sub-Saharan African nations

\begin{tabular}{|c|c|c|c|c|c|c|c|}
\hline \multirow{2}{*}{$\frac{\text { Nation }}{\text { Benin }}$} & \multicolumn{2}{|l|}{ Bivariate } & \multicolumn{2}{|c|}{ Socioeconomic $^{\mathrm{a}}$} & \multicolumn{2}{|c|}{ Political attitudes ${ }^{\mathrm{b}}$} & \multirow{2}{*}{$\frac{N}{1,196}$} \\
\hline & $-.21 * * *$ & $(.02)$ & $-.17 * * *$ & $(.02)$ & $-.16^{* * * *}$ & $(.02)$ & \\
\hline Botswana & -.05 & $(.03)$ & $-.06^{*}$ & $(.03)$ & -.05 & $(.03)$ & 1,199 \\
\hline Cape Verde & $-.14 * * *$ & $(.03)$ & $-.11 * * *$ & $(.03)$ & $-.09 * *$ & $(.03)$ & 1,245 \\
\hline Ghana & $-.34 * * *$ & $(.03)$ & $-.30 * * *$ & $(.04)$ & $-.27 * * *$ & $(.04)$ & 1,171 \\
\hline Kenya & $-.22 * * *$ & $(.03)$ & $-.18 * * *$ & $(.03)$ & $-.15^{* * *}$ & $(.03)$ & 1,275 \\
\hline Lesotho & $-.23 * * *$ & $(.04)$ & $-.23 * * *$ & $(.04)$ & $-.20 * * *$ & $(.04)$ & 1,119 \\
\hline Madagascar & $-.11 * * *$ & $(.02)$ & $-.09 * * *$ & $(.02)$ & $-.06^{* *}$ & $(.02)$ & 1,345 \\
\hline Malawi & $-.20 * * *$ & $(.03)$ & $-.19 * * *$ & $(.03)$ & $-.18 * * *$ & $(.03)$ & 1,198 \\
\hline Mali & $-.28 * * *$ & $(.03)$ & $-.24 * * *$ & $(.03)$ & $-.22 * * *$ & $(.03)$ & 1,237 \\
\hline Mozambique & $-.12 * * *$ & $(.03)$ & -.06 & $(.03)$ & -.04 & $(.03)$ & 1,122 \\
\hline Namibia & -.03 & $(.03)$ & -.03 & $(.03)$ & -.02 & $(.03)$ & 1,188 \\
\hline Nigeria & $-.21 * * *$ & $(.02)$ & $-.17 * * *$ & $(.02)$ & $-.14 * * *$ & $(.02)$ & 2,355 \\
\hline Senegal & $-.15 * * *$ & $(.03)$ & $-.07 *$ & $(.03)$ & -.06 & $(.03)$ & 1,192 \\
\hline South Africa & $-.05^{* *}$ & $(.02)$ & $-.05 * *$ & $(.02)$ & $-.04^{*}$ & $(.02)$ & 2,365 \\
\hline Tanzania & $-.26 * * *$ & $(.04)$ & $-.20 * * *$ & $(.04)$ & $-.18 * * *$ & $(.04)$ & 1,297 \\
\hline Uganda & $-.24 * * *$ & $(.02)$ & $-.17 * * *$ & $(.02)$ & $-.15 * * *$ & $(.02)$ & 2,399 \\
\hline Zambia & $-.12 * * *$ & $(.02)$ & $-.09 * * *$ & $(.02)$ & $-.07 * *$ & $(.02)$ & 1,188 \\
\hline
\end{tabular}

$* p<.05 ; * * p<.01 ; * * * p<.001$; two-tailed tests Source: Afrobarometer 2005

Bold values indicate coefficients are significantly different $(p<.05$; two-tailed test) from bivariate model

a Model controlling for age, age square, education, religious denomination, church attendance, employment, urban residence, poverty

b Socioeconomic model plus controls for trust in political institutions, political efficacy and interest in public affairs

contact politicians or political institutions. Similarly to collective action, we find that in Mozambique gender differences are no longer significant when controlling for socioeconomic characteristics. All other gender gaps remain significant when political attitudes are controlled for, with the exception of Senegal.

Comparing coefficients across models, we again find that standard controls only significantly mediate the gender gap in three nations: Nigeria, Senegal and Uganda. Only in Senegal does this drop the gender gap to insignificance. As with collective action, gender differences in political contact seem robust to controls for socioeconomic status and political attitudes.

\section{The Context of Political Participation: Exploring Cross-National Differences}

The above results indicate a weak gender gap in registering to vote, where socioeconomic and political attitudinal characteristics tend to largely explain differences between men and women's probability of registering. However, women remain much less likely than men to engage in collective actions or contact politicians or political institutions, regardless of their socioeconomic resources or political attitudes. Nevertheless, the nations do vary in the size and patterns of these gaps, suggesting important variation among the sub-Saharan 
Table 4 Correlations between country-level indicators and coefficients from bivariate regression models of women's likelihood of registering to vote, collective action, and political contact

\begin{tabular}{|c|c|c|c|}
\hline \multirow{2}{*}{ Contextual indicators } & \multicolumn{3}{|c|}{ Gender gaps in } \\
\hline & $\begin{array}{l}\text { Registration } \\
\text { to vote } \\
r\end{array}$ & $\begin{array}{l}\text { Collective } \\
\text { action } \\
r\end{array}$ & $\begin{array}{l}\text { Political } \\
\text { contact }^{\mathrm{a}} \\
r\end{array}$ \\
\hline \multicolumn{4}{|l|}{ Political factors } \\
\hline Level of civil and political rights ${ }^{\mathrm{a}}$ & .08 & -.15 & .21 \\
\hline Political stability and absence of violence/terrorism ${ }^{\mathrm{b}}$ & .39 & .27 & .43 \\
\hline Government effectiveness ${ }^{\mathrm{b}}$ & .33 & .17 & $.56^{*}$ \\
\hline Control of corruption ${ }^{\mathrm{b}}$ & .44 & .27 & $.64^{*}$ \\
\hline \multicolumn{4}{|l|}{ Economic factors } \\
\hline GDP per capita, PPP (full sample) ${ }^{c}$ & $.56^{*}$ & .42 & $.73^{*}$ \\
\hline GDP per capita, PPP (dropping outliers) ${ }^{c, d}$ & $.52 *$ & .06 & .06 \\
\hline Gini coefficient ${ }^{\mathrm{c}, \mathrm{e}}$ & $.47 *$ & $.56^{*}$ & $.68^{*}$ \\
\hline \multicolumn{4}{|l|}{ Social factors } \\
\hline Life expectancy at birth ${ }^{c}$ & -.14 & -.19 & -.10 \\
\hline Education index (adult literacy and gross enrolment $)^{c}$ & $.57 *$ & .39 & .46 \\
\hline \multicolumn{4}{|l|}{ Gender-related factors } \\
\hline$\%$ Women in legislature ${ }^{\mathrm{f}}$ & .08 & .45 & .25 \\
\hline$\%$ Women in ministerial positions ${ }^{\mathrm{c}}$ & $.51 *$ & .20 & .40 \\
\hline Year women could vote ${ }^{c}$ & .34 & $.55^{*}$ & $.57^{*}$ \\
\hline Female/male earned income ratio ${ }^{c}$ & -.45 & .03 & $-.50 *$ \\
\hline
\end{tabular}

\footnotetext{
$* p \leq 05$; two-tailed test

${ }^{a}$ Average of political rights and civil liberties scores for 2005 as reported by Freedom House (www. freedomhouse.org) recoded so that higher scores indicate more right/liberties

b Data for 2005 as collected by the Worldwide Governance Indicators (WGI) project and publically available through the World Bank (http://info.worldbank.org/governance/wgi/index.asp) (Kaufmann et al. 2009)

c Data reported by the 2007 UN Human Development Report based mainly on 2005 figures (http://hdr. undp.org/en/media/HDR_20072008_EN_Complete.pdf)

d Botswana, South Africa, and Namibia were all more than a standard deviation higher than the median and dropped as outliers

e Cape Verde is missing for this indicator

f 2005 data obtained from the International Parliamentary Union
}

region. Therefore, we briefly explore some potential linkages between the gender gaps we found earlier and each nation's structural socioeconomic, political and social characteristics. Table 4 presents correlations between the regression coefficients for the bivariate gender gap we found in each nation and a variety of contextual indicators that have been used in prior research on modernization theory and have been found to be related to gender gaps in political participation and gender equality more general in Western industrialized nations and across the world (e.g., Atkeson 2003; Desposato and Norrander 2009; Inglehart et al. 2002; Inglehart and Norris 2003; Marien, Hooghe and Quintellier 2010; Wolbrecht and Campbell 2007). 
As we see in Table 4, many contextual indicators are not significantly correlated with the gender gaps in political participation. Among the political factors, ${ }^{9}$ an effective government and control of corruption are positively correlated to women's likelihood of political contact. In other words, in countries where citizens perceive the government as being effective and in better control of corruption, men and women have more equal levels political contact. Yet, such political circumstances are not significantly related to collective action or registration to vote, though the relationship between perceptions of corruption and voter registration are only marginally insignificant $(p=.06)$.

Turning to the economic factors, the correlation coefficients indicate a significant relationship between economic inequality measured by the Gini coefficient and women's likelihood of engaging in all types of political participation. The higher the level of income inequality, the more likely women will register to vote, take part in collective actions or contact politicians or institutions. Smaller gender gaps in registration to vote are also found in the economically more prosperous sub-Saharan African countries, as indicated by the GDP per capita. Social factors seem to matter very little, though higher levels of education are positively related to women's voter registration, and are marginally related to political contact $(p=.06) .^{10}$

Finally, among the gender-related indicators, the longer women have had formal voting rights the more equal women's and men's participation in collective action and political contact. Yet, perhaps surprisingly, this is not significantly related to women's likelihood of registering to vote. ${ }^{11}$ Women's formal political power is at least partially related to gender equality in registering to vote. Countries where the gender gap in voter registration is smaller have more women in ministerial positions, but not in legislature. This suggests that gender equality is not just about being elected, but women obtaining power in the government itself at least when it comes to institutional political participation. Women's formal role in ministries does not matter for the gender gap in the less institutional types of participation. Yet, the relationship between the percent of women in legislator and collective action is marginally significant $(p=.06)$, which is suggestive of women's direct involvement in collective efforts to elect more women. Finally, the female/male earned income ratio is negatively and significantly related to women's likelihood to contact politicians or political institutions, and marginally negatively related to the gender gap in voter registration $(p=.06)$ indicating that across sub-Saharan African nations gender gaps in some forms of participation shrink where gender inequality in income is smaller.

\footnotetext{
${ }^{9}$ Political factors include: The level of civil and political rights are from Freedom House scores (www.fredomhouse.org) and indicators from the Worldwide Governance Indicators (WGI) project (http://info.worldbank.org/governance/wgi/index.asp) including: Government effectiveness_perceptions of the quality of public services, the quality of the civil service and the degree of its independence from political pressures, the quality of policy formulation and implementation, and the credibility of the government's commitment to such policies; Political Stability-perceptions of the likelihood that the government will be destabilized or overthrown by unconstitutional or violent means, including politicallymotivated violence and terrorism; and Control of Corruption-perceptions of the extent to which public power is exercised for private gain, including both petty and grand forms of corruption, as well as "capture" of the state by elites and private interests (Kaufmann et al. 2009).

${ }^{10}$ All economic, social and gender (with the exception of percentages of women in legislature which are obtained from the International Parliamentary Union) indicators were obtained from the UN Human Development Report from 2007, mostly based on 2005 data (http://hdr.undp.org/en/media/HDR_2007 2008_EN_Complete.pdf).

11 The same pattern of results - though even slightly stronger-was found when using the year women were allowed stand for elected office (results not shown but available upon request).
} 


\section{Conclusion and Discussion}

Equality in political participation is considered a key component of a healthy democracy, thus making inequality a popular topic in research on established democracies. Among the inequalities studied, gender gaps wherein women are less politically engaged than men have been a consistent finding (though for voting this gap has reversed in the U.S. since the mid-eighties (Currell 2005; Uhlaner 1989; Verba et al. 1997)). Yet, research on gender inequalities in political participation among unconsolidated democracies has lagged, and almost no research has comparatively tested gender gaps among and between African nations. As these nations transition into more stable democracies based on the premise of equal participation, investigations into participatory inequalities are warranted-if not overdue. Examining the involvement of women in politics may be particularly enlightening given research showing the transformative effect of women's formal political participation on politics in general (e.g., Uganda (Tamale 1999), and numerous studies in industrialized nations (e.g., Bystydzienski 1992; Hobson and Lindholm 1997), as well as global reports (e.g., Waring, et al. 2000)).

Such studies can now be conducted due to relatively recently available public opinion surveys on political behavior and attitudes conducted in developing countries. Using one such study, the 2005 Afrobarometer, this study's goal is to describe and explain the gender gap in political participation across 18 sub-Saharan African countries. Results indicate that the size and pattern of the gender gaps in political participation in sub-Saharan African nations share some similarities with findings from Western industrialized democracies. In line with prior research on Western industrialized nations (e.g., Coffé and Bolzendahl 2010), the gender gap is smaller in the measure of the most institutionalized form of political participation-registration to vote. In the African context, gender gaps in votingrelated behavior may be smaller since more institutionalized forms of participation may be 'safer' arenas for women to participate (Geisler 2004). In any case, variation in the gender gap among different modes of participation underline the importance of considering a variety of participation measures. Yet, unlike some findings from Western democracies, there is no evidence that women are more likely to register to vote than men, even controlling for socioeconomic and attitudinal characteristics. Moreover, socioeconomic status and political attitudes rarely mediate the gender gap in collective and contact actions (Schlozman et al. 1994; Coffé and Bolzendahl 2010). Thus, explanations for sources of gender differences based on prior work on industrialized nations appear to have weaker explanatory power in sub-Saharan African nations.

The results suggest evidence for both modernization and cultural isomorphic processes. First, relatively larger and more robust gender gaps would be expected based on modernization theories, and our evidence suggests this is the case. However, the pattern in the gender gaps across types of participation also suggest evidence that isomorphism is at work given that, as in industrialized democracies, the gender gap is smallest in the most institutional forms of participation. It may also reflect priorities conveyed by international governmental and non-governmental groups (IGOs and INGOs) (e.g., the UN, the World Bank), such as encouraging women to become more involved in elections and formal politics.

As is common in more global studies, focusing only on general patterns in gender gaps obscures cross-national differences within this region. Indeed, we find important differences across the region, underscoring the importance of examining results for individual nations. Voting - thus registering to vote-is arguably the key democratic right. Therefore, it is positive news that in most of these nations, there is no gender difference in registering 
to vote (Botswana, Cape Verde, Ghana, Lesotho, Malawi, South Africa, Zambia, and Zimbabwe). Another group of nations is hampered by gender differences in socioeconomic resources which in turn limit women's registration (Benin, Uganda, Madagascar, Mali, Mozambique, Namibia, Senegal, and Tanzania). If women had the same socioeconomic profile as men in these nations, they would register to vote in roughly equal amounts, while Nigeria would also need women to have political attitudes and interest similar to men in order to register equally to men. Kenyan women remain the least likely to register.

In terms of collective action, some nations emerge as quite different from their neighbors. The gap is small and quickly ameliorated by socioeconomic controls in Mozambique, and in Namibia, there is no gender gap, but if Namibian women had the same socioeconomic and attitudinal profile as Namibian men, they would be more likely to participate. Further, both Zambian and Zimbabwean women would be as likely as men to participate if they held similar socioeconomic resources and political attitudes. For all other nations, significant gender gaps remain even when gender differences in socioeconomic characteristics and political attitudes have been controlled for. Women and men in Botswana and Namibia tend to be equally engaged in political contact, while women in Mozambique and Senegalese women would do so if their resources and attitudes matched men. Overall, these differential patterns tell us that participation matters in various ways for men and women both across type of participation and nation examined.

Therefore, in the final part of our study, we explored some linkages between countrylevel social, political and economic context characteristics and the size of bivariate gender gaps in participation. As such, we provide exploratory insights into possible explanations for cross-national differences within the sub-Saharan African region. Our findings suggest modernization has a role in shaping equal outcomes across sub-Saharan African nations. The length of time a nation has permitted women to vote and the presence of women in ministerial positions, and other development indicators such as GDP per capita are positively linked to gender equality in participation. This is also reflected in our regression results which showed that two of wealthiest nations, Botswana and Namibia, often have the smallest gender gaps. However, we find that many of the macro-level measures do not seem to correlate very strongly with gender gaps in political participation and those that are significant seem to matter domain-specifically. The unevenness in these patterns suggests that progress itself is uneven and that gender gaps in political participation may reflect processes of cultural isomorphism where exposure to varying global influences differentially affect development. Together these findings tend to reflect recent critiques of modernization theory such that although some characteristics of development matter in pushing women's equality forward, it is only through careful attention to context-specific effects that we can unravel the unevenness in this process (Adams and Orloff 2005a, b).

Further research is needed to study the impact of context on the extent of the gender gap. Along these lines, such research may provide additional insight into reasons why gender gaps are explained by socioeconomic resources and political attitudes in some nations and not others. A final challenge for future work on gender and political participation in sub-Saharan African nations would be to invest the implications of gender gaps for political outcomes and gender equality in the region. Several studies have established a link between women's participation in public politics and particular policy outcomes (Bolzendahl and Brooks 2007; Iversen and Rosenbluth 2006; Manza and Brooks 1998; Schwindt-Bayer 2006). By investigating this link in developing nations such as the subSaharan countries, social and political science scholars could test to what extent women can put pressure on developing regimes by their political participation and as such add to the policymaking community and research. 
Open Access This article is distributed under the terms of the Creative Commons Attribution Noncommercial License which permits any noncommercial use, distribution, and reproduction in any medium, provided the original author(s) and source are credited.

\section{Appendix}

\section{See Table 5.}

Table 5 Means/proportions for explanatory variables (standard errors in parentheses) across 18 African countries

\begin{tabular}{|c|c|c|c|c|c|c|}
\hline & Range & Men & & \multicolumn{2}{|l|}{ Women } & Sig. Test $^{\mathrm{a}}$ \\
\hline \multicolumn{7}{|l|}{ Dependent variables } \\
\hline Registered to vote & $0-1$ & .82 & $(.00)$ & .78 & $(.00)$ & $*$ \\
\hline$N$ & & 12,666 & & 12,645 & & \\
\hline Collective action & $0-4$ & 2.24 & $(.01)$ & 1.87 & $(.01)$ & $*$ \\
\hline$N$ & & 12,583 & & 12,491 & & \\
\hline Political contact & $0-3$ & .37 & $(.01)$ & .20 & $(.00)$ & $*$ \\
\hline$N$ & & 12,060 & & 12,031 & & \\
\hline \multicolumn{7}{|l|}{ Control variables } \\
\hline Age & $18-99$ & 38.19 & $(.14)$ & 35.09 & $(.12)$ & $*$ \\
\hline \multicolumn{7}{|c|}{ Education (Ref. less than primary) } \\
\hline Completed primary & $0-1$ & .36 & $(.00)$ & .35 & $(.00)$ & NS \\
\hline Greater than primary & $0-1$ & .28 & $(.00)$ & .21 & $(.00)$ & $*$ \\
\hline Christian & $0-1$ & .63 & $(.00)$ & .66 & $(.00)$ & $*$ \\
\hline Church attendance & $0-5$ & 3.09 & $(.01)$ & 3.26 & $(.01)$ & NS \\
\hline Employed part or full time & $0-1$ & .43 & $(.00)$ & .31 & $(.00)$ & $*$ \\
\hline Urban residence & $0-1$ & .38 & $(.00)$ & .38 & $(.00)$ & NS \\
\hline Degree of poverty & $0-4$ & 1.27 & $(.01)$ & 1.29 & $(.01)$ & NS \\
\hline Trust political institutions & $0-3$ & 1.67 & $(.01)$ & 1.66 & $(.01)$ & NS \\
\hline Political efficacy & $0-4$ & 1.28 & $(.01)$ & 1.18 & $(.01)$ & $*$ \\
\hline Interest public affairs & $0-3$ & 2.04 & $(.01)$ & 1.73 & $(.01)$ & $*$ \\
\hline$N$ & & 12,702 & & 12,695 & & \\
\hline
\end{tabular}

Source: Afrobarometer 2005

$N S$ not significant

a Significance tests conducted through regressions with robust standard errors clustered by nation

$* p<.05$

\section{References}

Adams, J., Clemens, E. S., \& Orloff, A. S. (Eds.). (2005). Remaking modernity: Politics, history and sociology. Durham, NC: Duke University Press.

Adams, J., \& Orloff, A. S. (2005a). Defending modernity. Politics \& Gender, 1, 166-182.

Adams, J., \& Orloff, A. S. (2005b). Once more into the breach with modernity: Rejoinder to inglehart and norris, and young. Politics \& Gender, 1, 500-508.

Allison, P. (2002). Missing data. Thousand Oaks, CA: Sage.

Alwin, D. F., Cohen, R. L., \& Newcomb, T. M. (1991). Political attitudes over the life span: The Bennington women after 50 years. Madison, WI: Wisconsin University Press. 
Andersen, K. (1975). Working women and political participation, 1952-1972. American Journal of Political Science, 19, 439-453.

Atkeson, L. R. (2003). Not all cues are created equal: The conditional impact of female candidates on political engagement. Journal of Politics, 65, 1040-1061.

Atkeson, L. R., \& Rapoport, R. B. (2003). The more things change the more they stay the same: Examining differences in political communication, 1952-2000. Public Opinion Quarterly, 67(4), 495-521.

Ballington, J. (1998). Women's parliamentary representation: The effect of list PR. Politikon: South African Journal of Political Studies, 25, 77-93.

Ballington, J. (Ed.). (2004). The implementation of quotas: African experiences. Stockholm: International IDEA.

Bauer, J. (2009). Women and the 2005 election in Liberia. Journal of Modern African Studies, 47, $193-211$.

Beck, L. J. (2003). Democratization and the hidden public. The impact of patronage networks on senegalese women. Comparative Politics, 35, 147-169.

Bolzendahl, C., \& Brooks, C. (2007). Women's political representation and welfare spending in 12 capitalist democracies. Social Forces, 85, 1509-1534.

Bratton, M. (1999). Political participation in a new democracy. Institutional considerations from Zambia. Comparative Political Studies, 32, 549-588.

Bratton, M. (2007). Formal versus informal institutions in Africa. Journal of Democracy, 18(3), 96-110.

Bratton, M., \& van de Walle, N. (1992). Popular protest and political reform in Africa. Comparative Politics, 24, 419-442.

Brownmiller, S. (1984). Femininity. New York: Simon \& Schuster.

Burns, N. (2007). Gender in the aggregate, gender in the individual, gender and political action. Politics \& Gender, 3, 104-124.

Burns, N., Schlozman, K. L., \& Verba, S. (1997). The public consequences of private inequality: Family life and citizen participation. American Political Science Review, 91, 373-389.

Bystydzienski, J. M. (Ed.). (1992). Women transforming politics: Worldwide strategies for empowerment. Bloomington, IN: Indiana University.

Carter, D. (2008). Afrobarometer. Data codebook for round 3 afrobarometer surveys in 18 African countries. Michigan: Michigan State University.

Coffé, H., \& Bolzendahl, C. (2010). Same game, different rules? Gender differences in political participation. Sex Roles, 62, 318-333.

Currell, B. C. (2005). Gender, presidential elections and public policy: Making women's votes matter. Journal of Women, Politics and Policy, 27(1), 31-50.

Dalton, R. J. (2008). Citizenship norms and the expansion of political participation. Political Studies, 56, 76-98.

Dalton, R. J., Van Sickle, A., \& Weldon, S. (2009). The individual-institutional nexus of protest behaviour. British Journal of Political Science, 40, 51-73.

Desposato, S., \& Norrander, B. (2009). The gender gap in Latin America: Contextual and individual influences on gender and political participation. British Journal of Political Science, 39, 141-162.

Evans, G., \& Rose, P. (2007). Support for democracy in Malawi: Does schooling matter? World Development, 35, 904-919.

Fox, R. L., \& Lawless, J. L. (2004). Entering the arena? Gender and the decision to run for office. American Journal of Political Science, 48, 264-280.

Fridkin, K., \& Kenney, P. (2007). Examining the gender gap in children's attitudes toward politics. Sex Roles, 56(3), 133-140.

Galston, W. A. (2001). Political knowledge, political engagement, and civic education. Annual Review of Political Science, 4, 217-234.

Geisler, G. (1995). Troubled sisterhood: Women and politics in Southern Africa. Case Studies from Zambia, Zimbabwe and Botswana. African Affairs, 94, 545-578.

Geisler, G. (2004). Women and the remaking of politics in Southern Africa. Negotiating autonomy, incorporation and representation. Uppsala: Nordiska Afrikainstitutet.

Gray, M. M., Kittilson, M. C., \& Sandholtz, W. (2006). Women and globalization: A study of 180 countries, 1975-2000. International Organization, 60, 293-333.

Harrison, L., \& Munn, J. (2007). Gendered (non)participants? What constructions of citizenship tell us about democratic governance in the twenty-first century. Parliamentary Affairs, 60, 426-436.

Hobson, B., \& Lindholm, M. (1997). Collective identities, women's power resources, and the making of welfare states. Theory and Society, 26(4), 475-508.

Hooghe, M., \& Stolle, D. (2004). Good girls go to the polling booth, bad boys go everywhere: Gender differences in anticipated political participation among American fourteen-year-olds. Women \& Politics, 26(3), 1-23. 
Inglehart, R. (1990). Culture shift in advanced industrial society. Princeton, NJ: Princeton University Press.

Inglehart, R. (1997). Modernization and Postmodernization: Cultural, economic, and political change in 43 societies. Princeton, NJ: Princeton University Press.

Inglehart, R., \& Norris, P. (2003). Rising tide. Gender equality and cultural change around the world. Cambridge: Cambridge University Press.

Inglehart, R., \& Norris, P. (2005). Modernization and gender equality: A response to Adams and Orloff. Politics \& Gender, 1, 482-492.

Inglehart, R., Norris, P., \& Welzel, C. (2002). Gender equality and democracy. Comparative Sociology, 1, 321-345.

Inglehart, R., \& Welzel, C. (2005). Modernization, culture change and democracy. New York: Cambridge University Press.

Iversen, T., \& Rosenbluth, F. (2006). The political economy of gender: Explaining cross-national variation in the gender division of labor and the gender voting gap. American Journal of Political Science, 50, $1-19$.

Kaufmann, D., Kraay, A., \& Mastruzzi, M. (2009). Governance matters VIII: Aggregate and individual governance indicators 1996-2008. The World Bank Development Research Group. Policy Research Working Paper 4978. http://info.worldbank.org/governance/wgi/index.asp.

Lijphart, A. (1997). Unequal participation: Democracy's Unresolved Dilemma. The American Political Science Review, 91, 1-14.

Lindberg, S. I. (2004). Women's empowerment and democratization: The effects of electoral systems, participation and experience in Africa. Studies in Comparative International Development, 39, $28-53$.

Long, J. S. (2007). Comparing group effects in nonlinear models: Statistical problems and substantive insights. Research Talk given at the University of Notre Dame: see also http://www.indiana. edu/ jslsoc/research.htm.

Lovenduski, J. (2005). Feminizing politics. Cambridge, UK: Polity Press.

Manza, J., \& Brooks, C. (1998). The gender gap in US presidential elections: When? Why? Implications? American Journal of Sociology, 103, 1235-1266.

Marien, S., Hooghe, M., \& Quintellier, E. (2010). Inequalities in non-institutionalized forms of political participation: A multi-level analysis of 25 countries. Political Studies, 58, 187-213.

Marshall, T. H. (1950). Citizenship and social class. Cambridge: Cambridge University Press.

McEwan, C. (2000). Engendering citizenship: Gendered spaces of democracy in South Africa. Political Geography, 19, 627-651.

McEwan, C. (2003). 'Bringing government to the people': Women, local governance and community participation in South Africa. Geoforum, 34, 469-481.

Meyer, J. W., Boli, J., Thomas, G. M., \& Ramirez, F. O. (1997). World society and the nation-state. American Journal of Sociology, 103, 144-181.

Mood, C. (2010). Logistic regression: Why we cannot do what we think we can do, and what we can do about it. European Sociological Review, 26, 67-82.

Nisbet, E. C. (2008). Media use, democratic citizenship and communication gaps in a developing democracy. International Journal of Public Opinion Research, 20, 454-482.

Parry, G., Moyser, G., \& Day, N. (1992). Political participation and democracy in Britain. Cambridge, UK: Cambridge University Press.

Pateman, C. 1988 [1970]. Participation and democratic theory. New York, NY: Cambridge University Press.

Paternoster, R., Brame, R., Mazerolle, P., \& Piquero, A. (1998). Using the correct statistical test for the equality of regression coefficients. Criminology, 36, 859-866.

Pattie, C., Seyd, P., \& Whiteley, P. (2003). Citizenship and civic engagement: Attitudes and behaviour in Britain. Political Studies, 51, 443-468.

Paxton, P., Kunovich, S., \& Hughes, M. M. (2007). Gender in politics. Annual Review of Sociology, 33, 263-284.

Rapoport, R. B. (1981). The sex gap in political persuading: Where the 'structuring principle' works. American Journal of Political Science, 25, 32-48.

Royston, P. (2004). Multiple imputation of missing values. Stata Journal, 4, 227-241.

Rubin, D. B. (1987). Multiple imputation for nonresponse in surveys. New York: Wiley.

Schlozman, K., Lehman, N., Burns, E., \& Verba, S. (1994). Gender and the pathways to participation: The role of resources. Journal of Politics, 56, 963-990.

Schwindt-Bayer, L. A. (2006). Still supermadres? Gender and the policy priorities of Latin American legislators. American Journal of Political Science, 50, 570-585.

Scribner, D., \& Lambert, P. A. (2010). Constitutionalizing difference: A case study analysis of gender provisions in Botswana and South Africa. Politics \& Gender, 6, 37-61. 
Tamale, S. (1999). When hens begin to crow: Gender and parliamentary politics in Uganda. Boulder, CO: Westview Press.

Uhlaner, C. J. (1989). Turnout in recent American presidential elections. Political Behavior, 11, 57-79.

Van der Meer, T., te Grotenhuis, M., \& Pelzer, Ben. (2010). Influential cases in multilevel modeling: A methodological comment. American Sociological Review, 75, 173-178.

Verba, S., Burns, N., \& Schlozman, K. L. (1997). Knowing and caring about politics: Gender and political engagement. Journal of Politics, 59(4), 1051-1072.

Waring, M., Greenwood, G., \& Pintat, C. (2000). Politics: Women's insight. Geneva: Inter-Parliamentary Union.

West, C., \& Zimmerman, D. H. (1987). Doing gender. Gender \& Society, 1, 125-151.

Wolbrecht, C., \& Campbell, D. E. (2007). Leading by example: Female members of parliament as political role models. American Journal of Political Science, 51(4), 921-939.

Young, I. M. (2003). The logic of Masculinist protection: Reflections on the current security state. Signs, 29, $1-25$.

Young, I. M. (2005). Modernity, empancipatory values, and power: A rejoinder to Adams and Orloff. Politics \& Gender, 1, 492-500. 